\title{
RAT SKELETAL MUSCLE CONTRACTILITY: THE ROLE OF BETA-ADRENOCEPTORS AND NITRIC OXIDE SYSTEM
}

PROSTRAN MILICA*, STOJANOVIĆ R*, TODOROVIĆ Z*, VUČKOVIĆ SONJA*, SAVIĆ-VUJOVIĆ KATARINA*, MEDIĆ BRANISLAVA*, GRAJIĆ $\mathrm{M}^{\star * *}$ and KADIJA M***

*University of Belgrade, Faculty of Medicine, Serbia

${ }^{*}$ Clinic for Physical and Rehabilitation Medicine, Clinical Center of Serbia, Belgrade ***Institute for Orthopaedic Surgery and Traumatology, Clinical Center of Serbia, Belgrade

(Received 15 th December 2010))

Both beta-adrenoceptors and the nitric oxide system play a significant role in the modulation of skeletal muscle contractility.

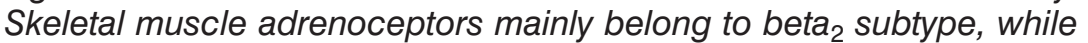
all three types of nitric oxide synthase may influence muscle contractility. The aim of our study was to investigate the possible interplay between beta-adrenoceptor agonists and nitric oxide system in the modulation of contractility of isolated rat hemidiaphragm. Adrenaline (0.05-1.5 $\mu \mathrm{mol} / \mathrm{L})$ and noradrenaline (1-5 $\mu \mathrm{mol} / \mathrm{L})$ given in a cumulative manner produced a concentration-related increase in $\mathrm{Td}$. L-NAME (1, 3 and $10 \mathrm{mmol} / \mathrm{L} ; 30 \mathrm{~min}$ of incubation) produced a significant, dose-dependent increase in $T d$ of the muscle pretreated with cumulative concentrations of adrenaline ( $\Delta T d$ up to $16 \%$ ). When hemidiaphragm was pretreated with noradrenaline instead of adrenaline, L-NAME (3 $\mathrm{mmo} / \mathrm{L}$ ) it produced a similar potentiation of $T d$. In conclusion, nitric oxide seems to oppose beta-adrenoceptor potentiation of diaphragm contractility, and such an interaction depends on previous adrenoceptor stimulation. Nitric oxide probably decreases beta-adrenoceptor response via cGMP-induced stimulation of phosphodiesterase 2. The interaction between substances which modulate NO system activity and CAMP levels in the skeletal muscle may be of a great clinical importance for the treatment of certain respiratory and neurological diseases.

Key words: adrenaline, beta-adrenoceptors, L-NAME, nitric oxide, rat skeletal muscle contractility

\section{INTRODUCTION}

In contrast to a well known explanation of the role of beta-adrenoceptor in the heart, recently we began to understand more about the beta signaling pathway in skeletal muscles. Beta-adrenoceptors are involved in several muscle functions: oxygen consumption, glycogenolysis, lipolysis, ion exchange and 
muscle contractility (Lynch and Ryall, 2008). Also, it was shown that some betaadrenoceptor agonist have the ability to increase skeletal muscle mass and decrease body fat (Emery et al., 1984).

Numerous studies have reported that skeletal muscles contain a significant number of $\beta$-adrenoceptors. Beta ${ }_{2}$-adrenoceptors are predominantly expressed in skeletal muscles from different species (Disatnik et al., 1990). Furthermore,

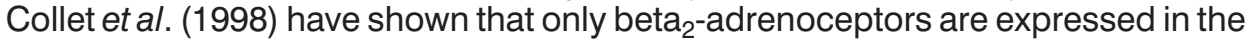
adult rat diaphragm. However, some authors found a significant population $(\approx 20 \%)$ of $\beta_{1}$-adrenoceptors in the soleus muscle (Kim et al., 1991$)$, as well as a smaller population of $\alpha$ adrenoceptors (Rattigan et al., 1986). Sillence et al. (1993) surmised the existence of atypical $\beta_{3}$-adrenoceptors in the rat soleus muscle. Also, Evans et al. (1999) have shown the existence of novel $\beta_{3}$-adrenoceptor subtypes (designated as $\beta_{3 a}$ and $\beta_{3 b}$-adrenoceptors) (Evans et al., 1999). It is believed, that both $\beta_{3}$-adrenoceptor subtypes may exert stimulatory effects mediated through $\mathrm{G} \alpha_{s}$ pathway. Furthermore, some authors (Hirata et al., 1986) observed the reduction in the number of sarcolemmal $\beta$-adrenoceptors and the occurrence of alpha-adrenoceptors in the rat soleus muscle, predominantly during hypokalemia.

There are two types of skeletal muscle fibres: type I fibres are designed for prolonged exertion (slow twitch fibres, $m$. soleus), and type II fibres are recruited during strenuous activities (fast twitch fibres, $m$. extensor digitorum longus). It has been documented that different types of skeletal muscle fibres express different densities and type of beta-adrenoceptors (Collet et al., 1998). The diaphragm is a muscle composed of an equivalent proportion of type I and type II fibres (Fratacci et al., 1996). It was shown that type I fibres contain a higher density of $\beta$ adrenoceptors (Martin et al., 1989).

The neuronal isoform of nitric oxide synthase (nNOS), most evident in fast fibres, has a major role in skeletal muscle contractility (Grozdanovic et al., 1997). It is documented that the activity of nNOS is regulated by calcium ions (Förstermann and Kleinert, 1995). The activity of nNOS can be upregulated during repetitive isometric contractions of skeletal muscles.

The aim of our study was to analyze the interaction between nitric oxide (NO) system and substances that modulate both the cAMP system and calcium metabolism in the skeletal muscle (e.g. adrenoceptor agonists), as well as the role of beta-adrenoceptors in such interactions.

\section{MATERIAL AND METHODS}

The experiments were performed on isolated rat hemidiaphragm. Wistar rats of both sexes (200-250 g) were bred and kept under standard laboratory conditions. The investigation conforms to the Guide For The Care and Use of Laboratory Animals published by the US National Institute of Health (NIH publication No. 85-23, revised 1985). The hemidiaphragms from male and female rats were suspended in an isolated organ bath of $20 \mathrm{~mL}$ capacity. The muscle was immersed in Tyrode solution with a double amount of glucose $(11.1 \mathrm{mM})$ and 
Acta Veterinaria (Beograd), Vol. 61, No. 4, 339-348, 2011.

bubbled with a mixture of $97 \% \mathrm{O}_{2}$ and $3 \% \mathrm{CO}_{2}$. The Tyrode solution composition was as follows: $136 \mathrm{mM} \mathrm{NaCl}, 2.81 \mathrm{mM} \mathrm{KCl}, 0.105 \mathrm{mM} \mathrm{MgCl}_{2}, 1.08 \mathrm{mM} \mathrm{CaCl}_{2}$, $0.417 \mathrm{mM} \mathrm{NaH}_{2} \mathrm{PO}_{4}, 11.9 \mathrm{mM} \mathrm{NaHCO}_{3}$ and $11.1 \mathrm{mM}$ dextrose. The temperature of the solution was $36^{\circ} \mathrm{C}$. Two paladore wires were used to deliver the pulses for direct electrical stimulation. The diaphragm was secured to one of these wires at several points along the rib line. The other electrode was placed around the upper part of the diaphragm, but was not in contact with the muscle. The initial tension after 30-min equilibration period was about $5 \mathrm{~g}$. The muscle was stimulated directly by subtetanic electrical stimulation. The frequency of stimulation was $14 \mathrm{~Hz}$ for $2 \mathrm{~s}$, and a series of pulses was applied every $12 \mathrm{~s}$ (5 times/min). The isometric contractions were recorded with a microdisplacement myograph transducer (F 50, Narco-Bio-System, Inc; Houston, TX, USA) and recorded on paper (Physiograph IV polygraph). Values for the developed tension (Td) were obtained (for details, see Prostran and Varagić, 1986; Prostran et al., 1993).

The effects of the used drugs were expressed as percentage changes of developed tension (Td) $(\Delta \mathrm{Td}$, \%) in relation to the corresponding control. The experimental design is shown in Fig. 1.

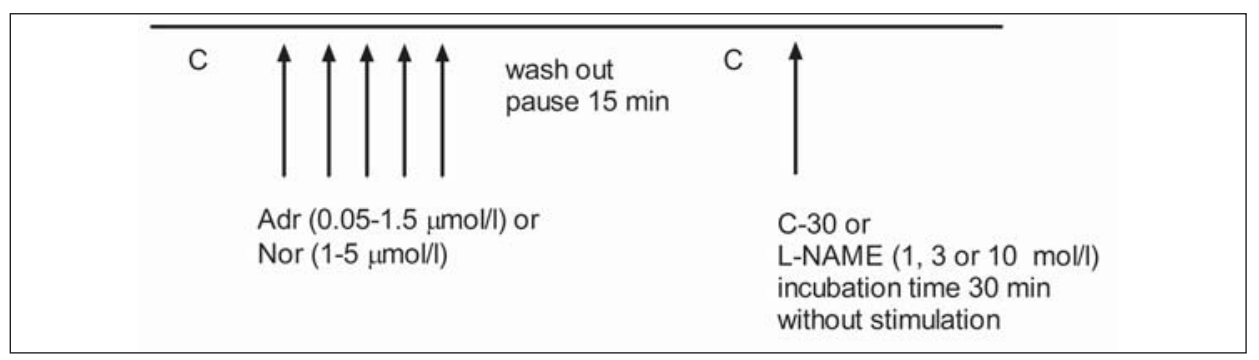

Figure 1. Experimental design.

C: the value of Td of the electrically stimulated muscle under basal conditions; C-30: the value of $\mathrm{Td}$ of the muscle, recorded after 30 min of incubation without L-NAME (Tyrode solution only), and without electrical stimulation; L-NAME: the value of Td of the electrically stimulated muscle recorded after 30 min of incubation with L-NAME $(1,3$, or $10 \mathrm{mmol} / \mathrm{L})$, as well as without electrical stimulation; Adr: adrenaline (cumulative concentrations of $0.05,0.15,0.35,0.75$, and $1.5 \mu \mathrm{mol} / \mathrm{L}$ ); Nor: noradrenaline (cumulative concentrations of $1,2,3,4$, and $5 \mu \mathrm{mol} / \mathrm{L}$ ).

The following drugs were used: L-noradrenaline bitartarate (Nor) (Serva, Heidelberg, Germany), epinephrine (Sigma Chemical Co., St. Louis, MO, USA), and $\mathrm{N}^{\mathrm{G}}$-nitro-L-arginine-methyl-ester (L-NAME, Sigma, St. Louis, MO, USA). Results are expressed as the mean \pm S.E.M. of $n$ determinations. Statistical analyses were performed with the software GraphPad Prism/Instat 1.1 (GraphPad Software; CA, USA) using nonlinear regression, one-way analysis of variance (ANOVA followed by post hoc 2-sided Dunnett's test), and Student's t-test, when appropriate. Values of $p<0.05$ were taken as statistically significant. 


\section{RESULTS}

Adrenaline (Adr) given in a cumulative manner $(0.05-1.5 \mu \mathrm{mol} / \mathrm{L})$ produced a concentration-related increase inTd ( $\Delta \mathrm{Td}$ up to $33 \%$; $\mathrm{EC}_{50}$ of $0.08 \mu \mathrm{mol} / \mathrm{L}, \mathrm{pD}_{2}$ of 7.08) (Fig. 2A).

Noradrenaline (Nor), also given in a cumulative manner (1-5 $\mu \mathrm{mol} / \mathrm{L})$ produced a concentration-related increase inTd ( $\Delta \mathrm{Td}$ up to $24 \% \mathrm{EC}_{50}$ of $1.11 \mu \mathrm{mol} / \mathrm{L}, \mathrm{pD}_{2}$ of 5.95) (Fig. 2B).
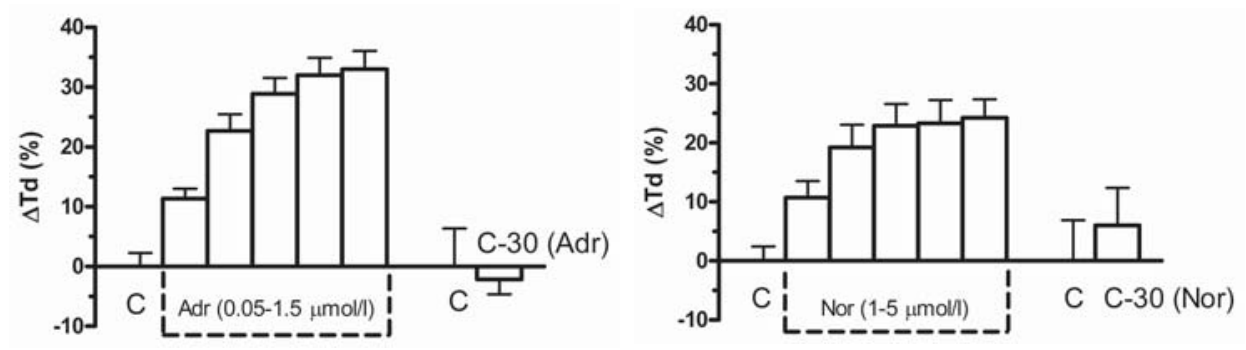

Figure 2. The effects of adrenaline and noradrenaline on $\mathrm{Td}$ of the isolated rat hemidiaphragm.

The effects of the repeated series of additions of adrenaline (Pannel A), and noradrenaline (Pannel $B$ ) on the isometric contraction of the isolated rat hemidiaphragm during direct subtetanic stimulation (Adr, 0.05-1.5 $\mu \mathrm{mol} / \mathrm{L}$; Nor, 1 $5 \mu \mathrm{mol} / \mathrm{L}) . \Delta \mathrm{Td}(\%)$ : the mean percentage change of $\mathrm{Td}$ from the corresponding control (C). C-30: the value of Td of the muscle recorded after 30 min of incubation without L-NAME (Tyrode solution only), and without electrical stimulation. Each vertical bar represents the mean + S.E.M. of 6-17 experiments

The next step was to investigate the effects of different concentrations of LNAME $(1,3$, and $10 \mathrm{mmol} / \mathrm{L})$ on the muscle pretreated with cumulative concentrations of $\mathrm{Adr}(0.5-1.5 \mu \mathrm{mol} / \mathrm{L})$. It was found that L-NAME (30 min of incubation) produced a significant, dose-dependent increase in $\mathrm{Td}$ of the muscle pretreated with cumulative concentrations of $\mathrm{Adr}$ ( $\Delta \mathrm{Td}$ up to $16 \%$; coefficient of determination, $r^{2}$ of $0.9990, P=0.02$ ) (Fig. 3, Pannels $A$ and $B$ ).

In a separate series of experiments, the hemidiaphragm was pretreated with Nor (1-5 $\mu \mathrm{mol} / \mathrm{L}$ ) instead of Adr. Again, L-NAME (3 mmol/L, $30 \mathrm{~min}$ of incubation) increased $\Delta \mathrm{Td}$ of the muscle pretreated with Nor. The effects of L-NAME (3 $\mathrm{mmol} / \mathrm{L})$ on $\Delta \mathrm{Td}$ were similar with both types of pretreatment, Adr and Nor (C-30 vs. L-NAME of $-2.40 \%$ vs. $4.40 \%$, and $6.00 \%$ vs. $10.33 \%$, respectively) (Fig. 3, Pannels $\mathrm{C}$ and D). 
Acta Veterinaria (Beograd), Vol. 61, No. 4, 339-348, 2011.

A

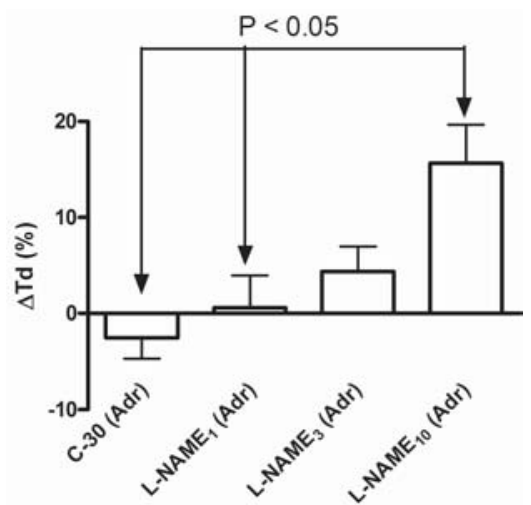

C

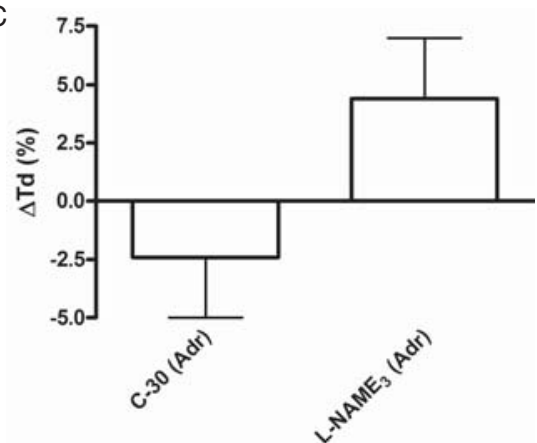

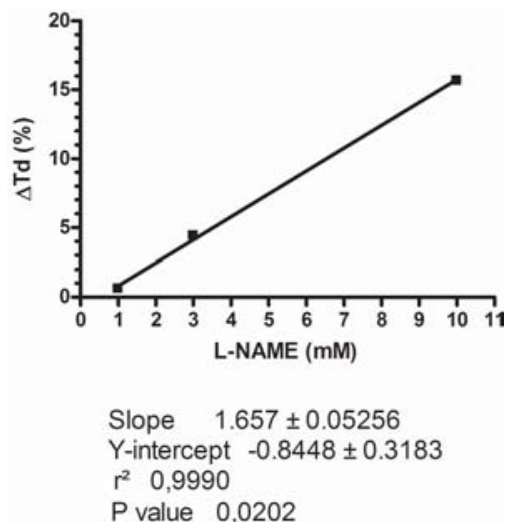

D

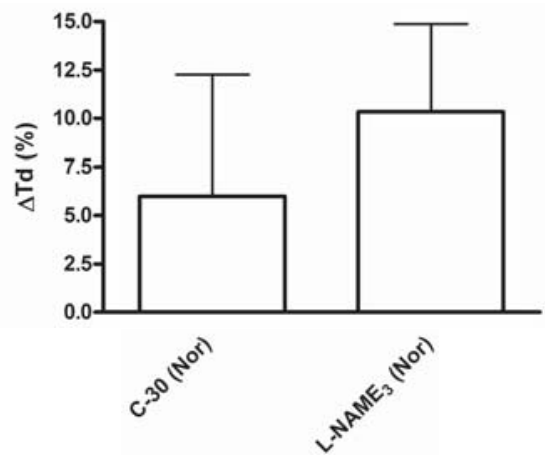

Figure 3. The interaction between adrenaline, noradrenaline and L-NAME on Td on the isolated rat hemidiaphragm.

Pannel A: Change of Td of the isolated rat hemidiaphragm pretreated with cumulative concentrations of adrenaline $(0.05-1.5 \mu \mathrm{mol} / \mathrm{L})$, during direct subtetanic electrical stimulation, after $30 \mathrm{~min}$ of incubation without or with L-NAME (1, 3 or $10 \mathrm{mmol} / \mathrm{L})$. $\Delta \mathrm{Td}(\%)$ : the mean percentage change of Td from the corresponding control (C). C30 (Adr): $\Delta \mathrm{Td}$ of the muscle pretreated with $\mathrm{Adr}$ (recorded after 30 min of incubation without L-NAME, and without electrical stimulation). L-NAME (Adr): $\Delta T$ Td of the muscle pretreated with Adr (recorded after 30 min of incubation with L-NAME, 1-10 mmol/L, and without electrical stimulation). Each vertical bar represents the mean + S.E.M. of 5-6 separate experiments. $\mathrm{P}<0.05$ (ANOVA with post-hoc 2 -sided Bonferroni's test). Pannel B: the concentration-response regression line for the effects of L-NAME (1$10 \mathrm{mmol} / \mathrm{L}$ ) on $\Delta \mathrm{Td}$ (pretreatment with Adr). Each point represents the mean from 5-6 separate experiments. Pannel C and D: Changes of Td of the rat hemidiaphragm pretreated with cumulative concentrations of adrenaline $(0.05-3 \mu \mathrm{mol} / \mathrm{L})$ or noradrenaline (1-5 $\mu \mathrm{mol} / \mathrm{L})$, after $30 \mathrm{~min}$ of incubation without or with L-NAME, $3 \mathrm{mmol} / \mathrm{L}$ (C-30 and L-NAME, respectively). Ordinate: $\Delta \mathrm{Td}(\%)$ : the mean percentage change of Td from the corresponding control $(C)$. Each vertical bar represents the mean + S.E.M. from 5-6 separate experiments 


\section{DISCUSSION}

Beta $_{2}$-adrenoceptor agonists, acting via cAMP, produce stimulation of fast skeletal muscle contraction. Activation of $\beta_{2}$-adrenoceptors leads to PKAdependent phosphorylation of SR calcium release channel (ryanodine receptor) and transient increase in intracellular calcium concentration. These changes were observed in both fast-twitch and slow-twitch muscles. In contrast to the fast-twitch muscles, phosphorylation of the phospholamban, an inhibitory protein associated with the SR calcium uptake pump, can only occur in slow twitch muscles, leading to faster relaxation of this type of muscles.

Some results suggest the association between the type of skeletal muscle fiber, corresponding beta-adrenoceptors subtype and the pattern of regulation of muscle contraction via activation of beta-adrenoceptors. Despite coexistence of different $\beta$-adrenoceptors in the skeletal muscle, one receptor subpopulation could be more efficiently coupled to the response mechanism(s) than another. It was explained by specific second messenger allocation and intracellular compartmentalization (Kenakin, 1997; Alexander et al., 2009). Also, it was shown that $\beta$-adrenoceptors density is in correlation with the percentage of type I fibres in muscle (Collet et al., 1998), as well as with oxidative potential (Williams et al., 1984). Jensen et al. (2002) found that beta-adrenoceptor density correlated closely with the percentage of type-I fibres and inversely with the percentage of type-IIB fibres. In addition, Murphy et al. (1997) observed that chronic 14-day administration of a selective $\beta_{2}$-adrenoceptor antagonist (ICl 118551) resulted in an upregulation of $\beta$-adrenoceptors in the rat lateral gastrocnemius muscle.

Our results show for the first time that pretreatment with both adrenoceptor agonists may influence the NO-mediated decrease in stimulated diaphragm contractility. A non-selective NOS inhibitor L-NAME produced a dose-dependent increase in Td in pretreated muscle (Fig. 3, A and B). We have previously shown that NO could not influence diaphragm contractility under basal conditions (i.e., previously untreated muscle) (Stojanović et al., 2003).

In a previously published paper (Todorović et al., 2006), we tried to answer some questions regarding adrenoceptor control of the skeletal muscle contractility during different types of electrical stimulation: direct single pulse (DSPES) and subtetanic (DSTES). Electrical stimulation (ES) itself could induce a biphasic calcium response in skeletal muscle: DSPES mainly triggers a fast calcium signal sensitive to ryanodine and tetanic stimulation induces a longlasting, inositol-triphosphate (IP3)-generated signal.

Noradrenaline in micromolar concentrations produced a concentrationrelated increase in $\mathrm{Td}$ despite the type of electrical stimulation. Atenolol, a selective $\beta_{1}$-adrenoceptor antagonist $(10 \mu \mathrm{M}, 10 \mathrm{~min})$ did not change the response to noradrenaline regarding slopes of the curves and $\mathrm{EC}_{50}$ and Emax values during both types of ES. The obtained result is consistent with results of

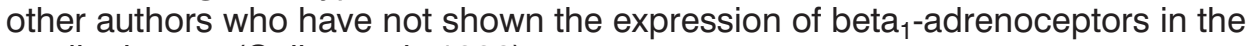
rat diaphragm (Collet et al., 1998).

On the other hand, ICl 118551, a selective $\beta_{2}$-adrenoceptor antagonist $(0.01,0.03$, and $0.1 \mu \mathrm{mol} / \mathrm{L} ; 10 \mathrm{~min})$ decreased the maximal response to 
Acta Veterinaria (Beograd), Vol. 61, No. 4, 339-348, 2011.

noradrenaline, and at the highest concentration, it almost completely abolished the effect of noradrenaline on Td during DSPES. However, during DSTES, in the presence of $\mathrm{ICl} 118551$, noradrenaline produced the maximal effect, but $\mathrm{ICl}$ 118551 significantly shifted noradrenaline curves to the right.

Based on these results, we concluded that the pattern of electrical stimulation of the muscle qualitatively changes the interaction between noradrenaline and $\beta$-adrenoceptor antagonists in the rat hemidiaphragm. In addition, $\beta_{2}$-adrenoceptors are probably involved in both types of electrical stimulation.

The neuronal isoform of nitric oxide synthase (nNOS), most evident in fast fibres, has a major role in skeletal muscle contractility (Grozdanovic et al., 1997). The activity of nNOS can be upregulated during repetitive isometric contractions of skeletal muscles. Therefore, the resting rat diaphragm produces approximately 3-5 pmol $\mathrm{NO}$ equivalents $/ \mathrm{mg} / \mathrm{min}$ of $\mathrm{NO}$, while during active isometric contractions, diaphragm nitric oxide production is increased approximately sixfold (Stamler and Meissner, 2001). Nitric oxide can modulate skeletal muscle contractility via at least two mechanisms: through cGMP-NO pathway, and directly, by interacting with calcium release channels of the sarcoplasmic reticulum (Reid, 1998; Stojanović et al., 2004).

In the present experiments, L-NAME potentiated Td of muscle pretreated with either Adr or Nor (Fig. 2). As NO production was blocked by L-NAME, the amount of nitric oxide was not enough to activate solubile guanilate cyclase (sGC). Decreased cGMP-induced stimulation of phosphodiesterase 2 (PDE2) which leads to decreased degradation of cAMP (Wallis et al., 1999). A raised cytosolic concentration of CAMP facilitates phosphorylation of calcium-ionconducting L-type channels and increases the likelihood of the channel being activated in response to stimulation. This mechanism could probably explain the potentiation of Td in the presence of L-NAME in muscle pretreated with betaadrenoceptor agonists. It is already known that nitric oxide does not affect calcium current under basal conditions, but modulates sympathomymetic-activated Lcalcium channels in cardiomyocytes (Brodde et al., 1999). It is quite possible to presume that such a mechanism exists in the skeletal muscle, as well.

Aminophylline (AMPh) modulates cAMP level by inhibiting phosphodiesterase (PDE) and produces an increase in the isometric contraction of the skeletal muscle. In the stimulatory action of AMPh on muscle contractility are probably involved both the enhanced calcium release from SR and the increased influx of extracellular calcium through sarcolemmal L-calcium channels (Prostran et al., 1993; Stojanović et al., 2004, 2005).

Under experimental conditions, during DSTES, L-NAME (non-selective inhibitor of NOS) increased tension developed (Td) in the muscle pretreated with cumulative concentrations of AMPh. As shown (Stojanović et al., 2003), pretreatment of the muscle with cumulative concentrations of AMPh (0.36$3.60 \mathrm{mmol} / \mathrm{L}$ ) could be a stimulus strong enough for upregulation of $\mathrm{nNOS}$. Therefore, observed potentiation of muscle contractility is most likely due to specific blockade of nNOs (i.e. the loss of the inhibitory effects of nitric oxide on diaphragm contraction). 
In previous studies, propranolol ( $1 \mu \mathrm{mol} / \mathrm{L} ; 30 \mathrm{~min}$ incubation) did not change Td itself, but abolished the stimulatory effect of L-NAME in the rat hemidiaphragm (Stojanović et al., 2005). On the other hand, atenolol (1 $\mu \mathrm{mol} / \mathrm{L}$, 30 min incubation) neither significantly changed Td nor L-NAME-induced potentiation of $\mathrm{Td}$.

\section{CONCLUSION}

In conclusion, pretreatment with adrenergic drugs may influence further response of the diaphragm to nitric oxide. Such an interaction may be of a great importance in the treatment of some respiratory and neurological disorders.

ACKNOWLEDGMENT:

This work was supported by the Ministry of Science, Republic of Serbia (grant No. 175023).

Address for correspondence:

Professor Dr Milica Prostran

Department of Pharmacology, Clinical Pharmacology and Toxicology

School of Medicine, University of Belgrade

P.O. Box 38

11120 Belgrade, Serbia

E-mail:mprostran@doctor.com

\section{REFERENCES}

1. Alexander SPH, Mathie A, Peters, JA, 2009, Guide to receptors and channels, 4th edition (2009 revision), Br J Pharmacol, 158 Suppl 1, S1-S254.

2. Brodde O-E, Michel MC, 1999, Adrenergic and muscarinic receptors in the human heart, Pharmacol Rev, 51, 651-89.

3. Collet F, Feve B, Frisdal E, Pavione C, Pecker F, Atlan G, 1998, Pharmacological and molecular characterisation of beta-adrenoceptors in adult rat diaphragm muscle, Respir Physio, 112, 112.

4. Disatnik MH, Sampson SR, Shainberg A, 1990, Characterization of beta-adrenoceptors on rat skeletal muscle cells grown in vitro, Biochem Pharmacol, 40, 1043-8.

5. Emery PW, Rothwell NJ, Stock MJ, Winter PD, 1984, Chronic effects of $\beta 2$-adrenergic agonists on body composition and protein synthesis in the rat, Biosci Rep, 4, 83-91.

6. Evans BA, Papaioannou M, Hamilton S, Summers RJ, 1999, Alternative splicing generates two isoforms of the â3-adrenoceptor which are differentially expressed in mouse tissues, $\mathrm{Br} \mathrm{J}$ Pharmacol, 127, 1525-31.

7. Förstermann U, Kleinert H, 1995, Nitric oxide synthase: expression and expressional control of the tree isoforms, Naunyn-Schmiedeberg's Arch Pharmacol, 352, 351-64.

8. Fratacci MD, Levame M, Rauss A, Bousbaa H, Atlan G, 1996, Rat diaphragm during postnatal development. I. Changes in distribution of muscle fibre type and in oxidative potential, Reprod Fertil Dev, 8, 391-8.

9. Grozdanovic Z, Christova T, Gossrau R, 1997, Differences in the localization of the postsynaptic nitric oxide synthase I and acetylcholinesterase suggest a heterogeneity of neuromuscular junctions in rat and mouse skeletal muscles, Acta Histochem, 99, 47-53.

10. Hirata A, Yoshida H, Oyama Y, Akaike N, 1986, Hypokalemia modulates alpha- and betaadrenoceptor bindings in rat skeletal muscle, Cell Mol Neurobiol, 6, 255-62. 
11. Jensen J, Brennesvik EO, Bergersen H, Oseland H, Jebens E, Brørs O, 2002, Quantitative determination of cell surface beta-adrenoceptors in different rat skeletal muscles, Pflugers Arch, 444, 213-9.

12. Kenakin TP, 1997, Pharmacologic analysis of drug-receptor interaction. Philadeplphia: LippincottRaven.

13. Kim YS, Sainz RD, Molenaar P, Summers RJ, 1991, Characterization of $\beta 1$ and $\beta 2$-adrenoceptors in rat skeletal muscles, Biochem Pharmacol, 42, 1783-9.

14. Lynch GS, Ryall JG, 2008, Role of $\beta$-adrenoceptor signaling in skeletal muscle: Implication for muscle wasting and disease, Physiol Rev, 88, 729-67.

15. Martin III W, Murphree S, Saffitz JB, 1989, -adrenergic receptor distribution among muscle fibre types and resistance arterioles of white, red and intermediate skeletal muscle, Circ Res, 64, 1096-105.

16. Murphy RJL, Gardiner PF, Rousseau G, Bouvier M, Beliveau L, 1997, Chronic $\beta$-blockade increases skeletal muscle beta adrenergic receptor density and enhances contractile force, $J$ Appl Physiol, 83, 459-65.

17. Prostran M, Todorović Z, Varagić VM, 1993, Some new evidence on antifatigue action of aminophylline on the isolated hemidiaphragm of the rat, Gen Pharmacol, 24, 225-32.

18. Prostran M, Varagic VM, 1986, The effect of forskolin on the isometric contraction of the isolated hemidiaphragm of the rat, Br J Pharmacol, 88, 791-7.

19. Rattigan S, Appleby GJ, Edwards SJ, Mc Kinstry WJ, Colquhoun EQ, Clark MG et al., 1986, $\alpha-$ adrenergic receptors in rat skeletal muscle, Biochem Biophys Res Commun, 136, 1071-7.

20. Reid $M B, 1998$, Role of nitric oxide in skeletal muscle: synthesis, distribution and functional importance, Acta Physiol Scand,162, 401-9.

21. Sillence MN, Moore NG, Pegg GG, Lindsay DB, 1993, Ligand binding properties of putative â3adrenoceptors compared in brown adipose tissue and in skeletal muscle membranes, $\mathrm{Br} J$ Pharmacol, 109, 1157-63.

22. Stamler JS, Meissner G, 2001, Physiology of nitric oxide in skeletal muscle, Physiol Rev, 81, 209-37.

23. Stojanović R, Todorović Z, Vučković S, Nešić Z, Prostran M, 2003, NG-nitro-L-arginine methyl ester potentiates the effect of aminophylline on the isolated rat hemidiaphragm, J Pharmacol Sci, 92 , 157-62.

24. Stojanović R, Todorović Z, Nešić Z, Vučković S, Cerovac-Ćosić N, Prostran M, 2004, NG-nitro-Larginine methyl ester-induced potentiaton of the effect of aminophylline on rat diaphragm: the role of extracellular calcium, J Pharmacol Sci, 96, 493-8.

25. Stojanović R, Todorović Z, Nešić Z, Vučković S, Prostran M, 2005, Aminophylline pretreatment modulates the nitric oxide system of the isolated rat diaphragm: the role of frequency of the electrical stimulation, J Pharmacol Sci, 99, 109-12.

26. Todorovic Z, Stojanovic R, Nesic Z, Divac N, Vojvodic N, Cerovac-Cosic N, et al., 2006, Type of electrical stimulation influences diaphragm response to adrenoceptor and calcium channel modulators: the role of extracellular and intracellular calcium events, J Pharmacol Sci,102, 34753.

27. Wallis RM, Corbin JD, Francis $S H$, Ellis $P$, 1999, Tissue distribution of phosphodiesterase families and the effects of sildenafil on tissue cyclic nucleotides, platelet function, and the contractile responses of trabeculae carneae and aortic rings in vitro, Am J Cardiol, 83, 3C-12C.

28. Williams RS, Caron MG, Daniel K, 1984, Skeletal muscle -adrenergic receptors: variations due to fiber type and training, Am J Physiol, 246, E160-E7. 


\title{
KONTRAKTILNOST SKELETNOG MIŠIĆA PACOVA: ULOGA BETA ADRENERGIČKIH RECEPTORA I SISTEMA AZOT OKSIDA
}

\author{
PROSTRAN MILICA, STOJANOVIĆ R, TODOROVIĆ Z, VUČKOVIĆ SONJA, \\ SAVIĆ-VUJOVIĆ KATARINA, MEDIĆ BRANISLAVA, GRAJIĆ M i KADIJA M
}

\section{SADRŽAJ}

Značajnu ulogu u modulaciji kontraktilnosti skeletnih mišića igraju i betaadrenoceptori i sistem azot oksida. Adrenoceptori u skeletnom mišiću pretežno pripadaju beta $_{2}$ podtipu, dok sve tri izoforme sintaze azot oksida mogu uticati na kontraktilnost mišića. Cilj našeg istraživanja je bio da ispitamo eventualne interakcije između beta-agonista sistema azot oksida u modulaciji kontraktilnosti izolovane hemidijafragme pacova. Adrenalin $(0,05-1,5 \mu \mathrm{mol} / \mathrm{L})$ i noradrenalin (1$5 \mu \mathrm{mol} / \mathrm{L})$, primenjeni kumulativno, dovode do koncentracijski-zavisnog porasta Td. L-NAME (1, 3 i 10 mmol/L; 30 min inkubacije) dovodi do značajnog, doznozavisnog porasta Td mišića koji je pretretiran kumulativnim koncentracijama adrenalina ( $\Delta \mathrm{Td}$ do $16 \%)$. Kada je hemidijafragma pretretirana noradrenalinom, a ne adrenalinom, L-NAME (3 mmol/L) je potencirao Td u sličnoj meri. Azot oksid izgleda smanjuje potenciranje kontraktilnosti izazvano aktivacijom betaadrenoceptora, a ishod takve interakcije zavisi od prethodne stimulacije adrenoceptora. Azot oksid verovatno smanjuje efekte stimulacije beta-adrenoceptora putem cGMP-zavisne stimulacije fosfodiesteraze 2. Interakcija između supstanci koje modulišu sistem azot oksida i nivo cAMP-a u skeletnom mišiću može imati značajnu ulogu u lečenju određenih respiratornih i neuroloških oboljenja. 